University of Nebraska - Lincoln

DigitalCommons@University of Nebraska - Lincoln

Agronomy \& Horticulture -- Faculty Publications

Agronomy and Horticulture Department

$5-1-2007$

\title{
Redistribution of crop residues during row cultivation creates a biologically enhanced environment for soil microorganisms
}

\author{
M. Susana Grigera \\ University of Nebraska-Lincoln \\ Rhae A. Drijber \\ University of Nebraska-Lincoln, rdrijber1@unl.edu \\ Brian J. Wienhold \\ University of Nebraska-Lincoln, Brian.Wienhold@ars.usda.gov
}

Follow this and additional works at: https://digitalcommons.unl.edu/agronomyfacpub

Part of the Plant Sciences Commons

Grigera, M. Susana; Drijber, Rhae A.; and Wienhold, Brian J., "Redistribution of crop residues during row cultivation creates a biologically enhanced environment for soil microorganisms" (2007). Agronomy \& Horticulture -- Faculty Publications. 31.

https://digitalcommons.unl.edu/agronomyfacpub/31

This Article is brought to you for free and open access by the Agronomy and Horticulture Department at DigitalCommons@University of Nebraska - Lincoln. It has been accepted for inclusion in Agronomy \& Horticulture -Faculty Publications by an authorized administrator of DigitalCommons@University of Nebraska - Lincoln. 


\title{
Redistribution of crop residues during row cultivation creates a biologically enhanced environment for soil microorganisms
}

\author{
M. Susana Grigera ${ }^{a}$, Rhae A. Drijber ${ }^{a}$, Brian J. Wienhold ${ }^{b, *}$ \\ ${ }^{a}$ Department of Agronomy and Horticulture, 279 Plant Science, University of Nebraska-Lincoln, \\ Lincoln, NE 68583-0915, United States \\ ${ }^{\mathrm{b}}$ USDA-ARS, 120 Keim Hall, University of Nebraska-Lincoln, Lincoln, NE 68583-0934, United States
}

Received 27 April 2006; received in revised form 23 August 2006; accepted 28 August 2006

\begin{abstract}
Formation of ridges during row cultivation creates microsites that could enhance spatial heterogeneity of soil properties, such as organic C, and thereby influence soil microbial communities. A study was conducted during 2003 near Shelton, NE, on a corn (Zea mays L.) field mapped using apparent electrical conductivity (ECa). New ridges were built each year with a row cultivator when corn reached the V3-V4 growth stage. Cultivation increased labile $\mathrm{C}$ fractions and soil microbial biomass in the row position for all ECa classes. Canonical discrimination analysis showed no clear differences in relative abundance of specific microbial groups among ECa classes or between row and furrow position, except for enhanced mycorrhizal biomass in the row. Microbial biomass responded strongly to changes in $\mathrm{C}$ redistribution, but was not accompanied by a significant change in the abundance of specific microbial groups. Labile $\mathrm{C}$ fractions (coarse and fine particulate organic matter) and crop residues in diverse stages of decomposition are associated with diverse microbial groups. Thus, row cultivation for weed control creates a biologically enhanced root zone that may improve early season performance of corn.
\end{abstract}

(C) 2006 Elsevier B.V. All rights reserved.

Keywords: Row cultivator; FAMEs; C availability; C redistribution

\section{Introduction}

Conventional tillage with mechanical cultivation has long been used to control weeds between the rows of corn, sorghum [Sorghum bicolor (L.) Moench.] and soybean [Glycine max (L.) Merr.] production (Burton et al., 2006). Ridges and furrows formed by row cultivation create spatial heterogeneity in biological and physical soil properties (Wander and Bollero, 1999). Ridge formation and associated residue movement

\footnotetext{
* Corresponding author.

E-mail address: bwienhold1@unl.edu (B.J. Wienhold).
}

modify soil water and solute movement (Bargar et al., 1999), and may influence soil microbial communities.

Soil microbial biomass represents only a small proportion $(<5 \%)$ of SOM, but due to its dynamic nature acts as a major sink and source of labile nutrients (Jenkinson and Ladd, 1981). Spatial and temporal dynamics of soil microbial biomass are good indicators of changes in soil biological processes (Pankhurst et al., 2002) related to organic matter transformations and nutrient cycling (Gupta et al., 1994). Microbial biomass has been shown to respond to tillage practice, phase of a crop-fallow cycle, and distribution of crop residue (Drijber et al., 2000; Pankhurst et al., 2002). Understanding how redistribution of $\mathrm{C}$ fractions during row cultivation affects soil microbial groups is important, 
because of the effect microorganisms have on soil chemical and physical properties. We reported on the utility of using apparent electrical conductivity (ECa) to delineate spatial variability in soil properties (Grigera et al., 2006); ECa was well correlated with inherent soil properties (e.g. clay content, depth of topsoil, and total dissolved solids) in the $0-90 \mathrm{~cm}$ soil layer. We also found that ECa was not well correlated with soil properties in the $0-30 \mathrm{~cm}$ soil layer due to the effect management practices such as tillage and fertilization have on soil properties in this layer. Here we tested the hypothesis that row cultivation redistributes crop residues creating row and furrow environments that differ in $\mathrm{C}$ availability and associated soil microbiological communities.

\section{Materials and methods}

A field study was conducted during 2003 near Shelton, NE $\left(40^{\circ} 45^{\prime} 01^{\prime \prime} \mathrm{N}, 98^{\circ} 46^{\prime} 01^{\prime \prime} \mathrm{W}\right)$. Soils at the site were Hord silt loam (fine-silty, mixed, mesic Pachic Argiustoll, 0-1\% slope) and Blendon loam (coarseloamy, mixed, mesic Pachic Haplustoll, 0-1\% slope). Continuous corn was grown from 1990 to 1996 under conventional disk-tillage with furrow irrigation and since 1996 under reduced tillage with sprinkler irrigation. Current tillage practices included disking the field in the fall following harvest to level past year ridges and incorporate crop residue, preparing the seedbed in the spring using a field cultivator, and planting corn at a row spacing of $76 \mathrm{~cm}$ in mid to late May. Corn was grown using agronomic practices common to the region, including row cultivation for weed control when the corn reached the V3-V4 growth stage (Ritchie et al., 1997).

In May 2003, spatial variability in soil properties was mapped using ECa measured with an EM 38 conductance meter (Geonics Ltd., Mississauga, Ontario, Canada) pulled behind an all-terrain vehicle. Data were logged at 1-s intervals $(\sim 2 \mathrm{~m})$ and georeferenced using a differential global positioning system receiver (Trimble Navigation, Sunnyvale, CA) mounted near the EM38 sensor. The ECa data were processed using unsupervised classification to delineate four classes within the field (Johnson et al., 2001). Within each ECa, class six sites were randomly selected for sampling. Soil samples were collected during the V6 stage of corn (Ritchie et al., 1997) on 20 June 2003. At each of the 24 locations, 10 soil cores (0-15 cm depth) were collected and composited from the row and 10 from the furrow position midway between two rows. The composite soil samples were placed in a cooler for transport to the laboratory. Soil was passed through a $4 \mathrm{~mm}$ sieve to remove visible organic residues, thoroughly mixed, and divided into two subsamples. One subsample was stored at $-18{ }^{\circ} \mathrm{C}$ for fatty acid analysis and the other was air-dried, passed through $2 \mathrm{~mm}$ sieve, and analyzed for clay content (Kettler et al., 2001), total soil organic matter (SOM), fine (0.053$0.5 \mathrm{~mm}$ ) particulate organic matter $(\mathrm{POM})$, and coarse (0.5-2 mm) POM by loss-on-ignition (Cambardella et al., 2001). Electrical conductivity $\left(\mathrm{EC}_{1: 1}\right)$ was measured in a 1:1 soil:water slurry (Smith and Doran, 1996). Total dissolved solids (TDS) were estimated by multiplying the $\mathrm{EC}_{1: 1}$ at $25{ }^{\circ} \mathrm{C}(\mathrm{dS} / \mathrm{m})$ by 0.64 (Smith and Doran, 1996). Soil bulk density was determined by dividing the oven dry weight of the soil by the volume of the sample. Organic matter, TDS, fine POM, and coarse POM were expressed on an equivalent mass basis (Ellert and Bettany, 1995).

Microbial biomass was determined as extractable lipid $\mathrm{P}$ on duplicate $1 \mathrm{~g}$ samples using perchloric acid digestion and then quantifying the released phosphate (Kates, 1986). Microbial community structure was based on extraction of total fatty acid methyl esters (FAMEs) by mild alkaline hydrolysis (Grigera et al., 2006). Fatty acids were identified by retention-time and confirmed by mass spectrometry. Five microbial groups were defined based on known FAME biomarkers. Bacteria were represented by FAME markers $i \mathrm{C} 15: 0$, $a \mathrm{C} 15: 0, \mathrm{C} 15: 0, i \mathrm{C} 16: 0, i \mathrm{C} 17: 0, a \mathrm{C} 17: 0, \mathrm{C} 17: 0$, and $\mathrm{C} 16: 1$ cis 7 , with the cyclopropane fatty acids cy $17: 0$ and cy 19:0 included as biomarkers for Gram-negative bacteria (Grogan and Cronan, 1997). Actinomycetes were represented by FAME markers $i 10 \mathrm{MeC} 18: 0$ and 10MeC18:0 (Kroppenstedt, 1985). Fungal communities were represented by C18:2cis9,12 (Stahl and Klug, 1996) and vesicular arbuscular mycorrhizal fungi were represented by C16:1cis11 (Olsson and Johansen, 2000).

Relationships between physical, chemical, and biological soil properties and ECa class were assessed by ANOVA (using PROC MIXED procedure) for a completely randomized design with ECa class and position (row versus furrow) as factors. Pearson correlation analysis was conducted to assess the linear association between ECa sample mean for each site and soil physicochemical and microbiological properties. Discriminant analysis was conducted on relative abundances of the defined microbial groups (bacteria, Gram-negative bacteria, actinomycetes, fungi, vesicular arbuscular mycorrhizal fungi) to determine linearly uncorrelated axes and to prioritize the separation of two or more groups of variables. All statistical analyses 
were performed using SAS (SAS Institute, 1999), and differences were declared significant at the 0.05 level, unless stated otherwise.

\section{Results and discussion}

The relationship between physical and chemical soil properties and ECa classes or row-furrow position in the $0-15 \mathrm{~cm}$ depth varied (Table 1). Clay content was greater in ECa Class III than in Class I and TDS were higher in Classes III and IV than in Classes I and II (Table 1). In contrast, bulk density and SOM were similar across ECa classes. Components of SOM also differed in their relationship to ECa class with fine POM being greater in ECa Class III than in ECa Classes I and II but coarse POM was similar among ECa classes. The relationship of physical and chemical soil properties to row-furrow position was consistent. Coarse POM, fine $\mathrm{POM}, \mathrm{SOM}$, and TDS were greater in the row than in the furrow. The increase in POM and SOM and lower bulk density in the row position (Table 1) was likely due to redistribution of soil and crop residue $\mathrm{C}$ with row cultivation. Clay content was similar in the row and furrow positions (Table 1). The interaction between ECa class and row-furrow position was not significant for any of the soil physical and chemical properties measured.

Microbial biomass and FAME biomarkers for bacteria, Gram-negative bacteria, and actinomycetes were higher in ECa Class III than Classes I, II and IV (Table 1). The FAME biomarker for mycorrhizae was greater in ECa Class II than in ECa Class IV. The FAME biomarker for fungi was similar across ECa classes. The interaction between ECa class and row-furrow position was significant for the mycorrhizal FAME biomarker $(p=0.05)$. Summed FAME biomarkers for all microbial groups was correlated with microbial biomass $(r=0.77)$ and was greater in the row position $\left(24.46 \mathrm{mmol} \mathrm{m}^{-2}\right)$ than in the furrow position $\left(19.18 \mathrm{mmol} \mathrm{m}^{-2}\right)$. Correlation between microbial biomass and total FAME biomarkers was stronger in the furrow $(r=0.85)$ than in the row $(r=0.60)$. Microbial biomass and FAME biomarkers for bacteria, Gram-negative bacteria, actinomycetes, fungi, and mycorrhizae were all greater in the row than in the furrow.

Although microbial biomass responded strongly to changes in $\mathrm{C}$ redistribution, no significant change in the abundance of specific microbial groups was observed. The canonical discriminant analysis identified two discriminant functions $(p<0.05)$. We used the first and second canonical functions (eigenvalues 1.32 and 0.95 ) that together explained $84 \%$ of the total variance. As observed in Fig. 1a there was no clear discrimination among the row and furrow position or by classes. However, samples from the row position were displaced towards the left within each ECa class analyzed. The most important fatty acid involved in this shift was the relative amount of mycorrhizal FAME biomarker, C16:1cis11 (Fig. 1b). Increased relative abundance of mycorrhizal fungi in the row position was likely due to the influence of living roots in this environment.

In conventional tillage systems, preplant tillage operations create more homogeneous soil conditions and redistribute applied fertilizers throughout the tilled layer (Kaspar et al., 1991). John et al. (2004) observed

Table 1

Mean values for soil physicochemical and biological properties in the furrow and in the row

\begin{tabular}{|c|c|c|c|c|c|c|c|c|c|c|c|}
\hline $\begin{array}{l}\text { Main } \\
\text { effect }\end{array}$ & $\begin{array}{l}\text { Clay } \\
\left(\mathrm{kg} \mathrm{m}^{-2}\right)\end{array}$ & $\begin{array}{l}\text { CPOM } \\
\left(\mathrm{g} \mathrm{m}^{-2}\right)\end{array}$ & $\begin{array}{l}\text { FPOM } \\
\left(\mathrm{g} \mathrm{m}^{-2}\right)\end{array}$ & $\begin{array}{l}\text { SOM } \\
\left(\mathrm{g} \mathrm{m}^{-2}\right)\end{array}$ & $\begin{array}{l}\text { TDS } \\
\left(\mathrm{g} \mathrm{m}^{-2}\right)\end{array}$ & $\begin{array}{l}\mathrm{BD} \\
\left(\mathrm{g} \mathrm{cm}^{-3}\right)\end{array}$ & $\begin{array}{l}\text { MB } \\
\left(\mathrm{mmol} \mathrm{m}^{-2}\right)\end{array}$ & $\begin{array}{l}\text { Bact } \\
\left(\mathrm{nmol} \mathrm{m}^{-2}\right)\end{array}$ & $\begin{array}{l}\text { Gram- } \\
\left(\mathrm{nmol} \mathrm{m}^{-2}\right)\end{array}$ & $\begin{array}{l}\text { Actino } \\
\left(\mathrm{nmol} \mathrm{m}^{-2}\right)\end{array}$ & $\begin{array}{l}\text { Fungi } \\
\left(\mathrm{nmol} \mathrm{m}^{-2}\right)\end{array}$ \\
\hline \multicolumn{12}{|l|}{ Class } \\
\hline ECa I & $32.2 b$ & $297.7 \mathrm{a}$ & $770.5 b$ & $5010.5 a$ & $55.2 \mathrm{~b}$ & $1.28 \mathrm{a}$ & $44.1 \mathrm{~b}$ & $3220.3 b$ & $963.9 \mathrm{~b}$ & $428.2 b$ & $2234.1 \mathrm{a}$ \\
\hline ECa II & $36.0 \mathrm{ab}$ & 268.1a & $776.9 \mathrm{~b}$ & $5228.1 \mathrm{a}$ & $54.4 \mathrm{~b}$ & $1.25 \mathrm{a}$ & $45.5 b$ & $3439.7 b$ & $1011.6 \mathrm{~b}$ & 495.3ab & $2038.6 a$ \\
\hline ECa III & $39.9 \mathrm{a}$ & $354.2 \mathrm{a}$ & $929.2 \mathrm{a}$ & $5959.0 \mathrm{a}$ & $63.7 \mathrm{a}$ & $1.21 \mathrm{a}$ & $57.0 \mathrm{a}$ & 4118.1a & $1183.0 \mathrm{a}$ & $573.2 \mathrm{a}$ & $2160.7 \mathrm{a}$ \\
\hline ECa IV & $36.5 \mathrm{ab}$ & $269.9 \mathrm{a}$ & $871.9 \mathrm{ab}$ & $5381.4 \mathrm{a}$ & $60.7 \mathrm{a}$ & $1.23 \mathrm{a}$ & $49.9 \mathrm{ab}$ & $3507.4 \mathrm{~b}$ & 949.1ab & $469.5 b$ & $1729.0 \mathrm{a}$ \\
\hline S.E. & 1.7 & 25.7 & 35.2 & 247.7 & 1.8 & 0.02 & 2.4 & 174.0 & 43.4 & 32.3 & 137.3 \\
\hline \multicolumn{12}{|l|}{ Position } \\
\hline Furrow & $36.3 \mathrm{~A}$ & $260.2 \mathrm{~B}$ & 770.9B & $5308.6 \mathrm{~B}$ & $54.6 \mathrm{~B}$ & $1.28 \mathrm{~A}$ & $45.3 \mathrm{~B}$ & 3198.1B & 949.1B & 448.6B & 1818.3B \\
\hline Row & $36.0 \mathrm{~A}$ & $334.7 \mathrm{~A}$ & $903.3 \mathrm{~A}$ & $5480.9 \mathrm{~A}$ & $62.3 \mathrm{~A}$ & $1.21 \mathrm{~B}$ & $53.0 \mathrm{~A}$ & 3944.7A & $1158.6 \mathrm{~A}$ & $534.4 \mathrm{~A}$ & $2262.9 \mathrm{~A}$ \\
\hline S.E. & 0.9 & 14.3 & 20.3 & 126.2 & 1.2 & 0.01 & 1.3 & 94.8 & 23.4 & 16.9 & 89.3 \\
\hline
\end{tabular}

CPOM, coarse particulate organic matter (0.5-2 mm); FPOM, fine particulate organic matter (0.053-0.5 mm); SOM, soil organic matter; TDS, total dissolved salts; $\mathrm{BD}$, bulk density; $\mathrm{MB}$, total microbial biomass measured as lipid $\mathrm{P}$; Bact, bacterial markers $(i \mathrm{C} 15: 0, a \mathrm{C} 15: 0, \mathrm{C} 15: 0, i \mathrm{C} 16: 0, i \mathrm{C} 17: 0$, $a \mathrm{C} 17: 0, \mathrm{C} 17: 0, \mathrm{C} 16: 1$ cis7); Gram-, cyclopropane bacterial markers (cyC17:0, cyC19:0); Actino, actinomycetes markers (i10MeC18:0, $10 \mathrm{MeC} 18: 0)$,); Fungi, fungal marker (C18:2cis 9,12$)$. Means followed by the same letter within ECa or position are not different $(p<0.05)$. $N=48$. 

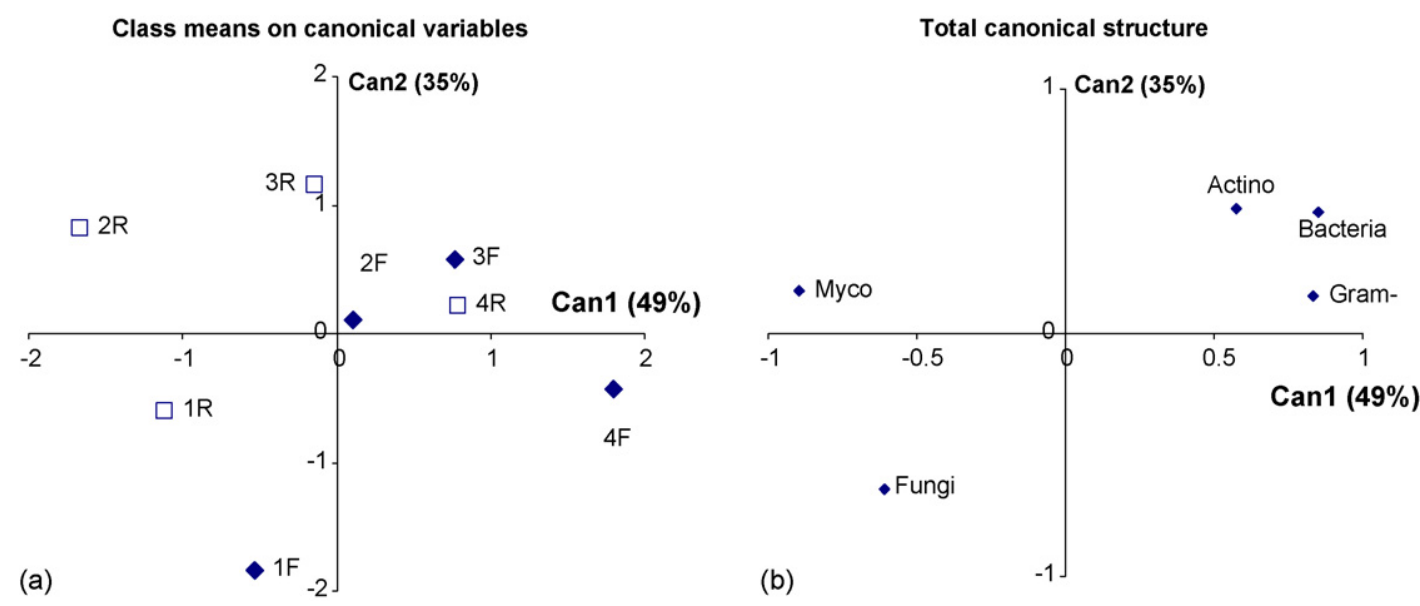

Fig. 1. Discriminant scores of treatments for (a) class means on canonical variables and (b), showing the two significant discriminant functions, Can 1 and Can2. $1 \mathrm{~F}=$ apparent electrical conductivity $(\mathrm{ECa})$ Class I furrow, $1 \mathrm{R}=\mathrm{ECa}$ Class I row, $2 \mathrm{~F}=\mathrm{ECa}$ Class II furrow, $2 \mathrm{R}=\mathrm{ECa}$ Class II row, $3 \mathrm{~F}=\mathrm{ECa}$ Class III furrow, 3R = ECa Class III row, 4F = ECa Class IV furrow, and 4R = ECa Class IV row. Bacteria, bacterial markers $(i \mathrm{C} 15: 0$, $a \mathrm{C} 15: 0, \mathrm{C} 15: 0, i \mathrm{C} 16: 0, i \mathrm{C} 17: 0, a \mathrm{C} 17: 0, \mathrm{C} 17: 0, \mathrm{C} 16: 1$ cis7); Gram-, cyclopropane bacterial markers (cyC17:0, cyC19:0); Actino, actinomycetes markers (i10MeC18:0, 10MeC18:0); Myco, mycorrhizal marker (C16:1cis11); Fungi, fungal marker (C18:2cis9,12). $N=48$.

homogeneity of the older soil organic $\mathrm{C}$ in the Ap horizon across row and furrow positions due to 40 years of plowing. Grigera et al. (2006) concluded that a similar condition was present in the same field prior to row cultivation. Tillage following harvest to incorporate crop residue and tillage in the spring to prepare the seedbed produced a relatively homogenous surface soil layer. This resulted in soil properties in the $0-30 \mathrm{~cm}$ layer not being as strongly correlated with $\mathrm{ECa}$ as those in the $0-90 \mathrm{~cm}$ layer. Row cultivation physically moved a portion of the soil containing incorporated residue from the previous year's crop to the row position resulting in differences in a number of physical and chemical soil properties (Table 1). Thus, redistribution of labile $\mathrm{C}$ fractions (FPOM and CPOM) and associated microbial biomass should have been largely due to row cultivation. There would have been less influence by the current crop on the composition of the soil community (with the exception of mycorrhizae) at this early stage of growth.

Redistribution of crop residues to form a biologically enhanced root zone may have significant implications for early season crop growth. John et al. (2004) observed that total emission of corn-derived $\mathrm{CO}_{2}$ (due to the mineralization of $\mathrm{C}_{4}$-soil organic $\mathrm{C}$ and corn residues) was three times greater for the row than for the furrow, while no difference was observed between row and furrow positions in the mineralization of native soil C. They also found that uneven distribution of corn residues resulted in increased heterotrophic activity in the row compared to the furrow. Similarly, we showed an increase in both POM fractions and microbial biomass in the row position. Consequently, row cultivation may enhance mineralization of corn residues during the growing season and thereby increase nutrient availability. Kaspar et al. (1991) observed that fertilizer placement altered root distribution, and that root length and weight in non-tracked furrows were greater than in tracked furrows. They stated that fertilizer injected into the row caused a proliferation of small-diameter roots. Thus, row cultivation may also increase corn root development, because of lower soil bulk density, higher nutrient availability and improved mycorrhizal relations.

In summary, uneven redistribution of corn residues due to ridge formation resulted in increased fine POM, coarse POM, and soil microbial biomass and decreased bulk density in the row environment when compared to the furrow. Although microbial biomass responded strongly to changes in $\mathrm{C}$ redistribution, it was not accompanied by a significant change in the abundance of specific microbial groups, indicating a shift in quantity rather than diversity of microorganisms. Increased microbial abundance provides greater opportunity for nutrient capture and turnover. Thus, row cultivation for weed control creates a biologically enhanced root zone that may improve early season performance of corn.

\section{Acknowledgments}

We thank Liz Jeske, Susan Siragusa, Susan Wagner, Paul Koerner for laboratory assistance and field data collection. We also thank Scott Stubblefield for 
allowing access to his field and willingness to provide management input data.

\section{References}

Bargar, B., Swan, J.B., Jaynes, D., 1999. Soil water recharge under uncropped ridges and furrows. Soil Sci. Soc. Am. J. 63, 12901299.

Burton, M.G., Mortensen, D.A., Lindquist, J.L., 2006. Effect of cultivation and within-field differences in soil conditions on feral Helianthus annuus growth in ridge-tillage maize. Soil Till. Res. 88, 8-15.

Cambardella, C.A., Gajda, A.M., Doran, J.W., Wienhold, B.J., Kettler, T.A., 2001. Estimation of particulate and total organic matter by weight loss on ignition. In: Lal, R., et al. (Eds.), Assessment Methods for Soil Carbon. CRC Press, Boca Raton, FL, pp. 349 359.

Drijber, R.A., Doran, J.W., Parkhurst, A.M., Lyon, D.J., 2000. Changes in soil microbial community structure with tillage under long-term wheat-fallow management. Soil Biol. Biochem. 32, 1419-1430.

Ellert, B.H., Bettany, J.R., 1995. Calculations of organic matter and nutrients stored in soil under contrasting management. Can. J. Soil Sci. 75, 529-538.

Grigera, M.S., Drijber, R.A., Eskridge, K.M., Wienhold, B.J., 2006. Soil microbial biomass relationships with organic matter fractions in a Nebraska corn field mapped using apparent electrical conductivity. Soil Sci. Soc. Am. J. 70, 1480-1488.

Grogan, D.W., Cronan Jr., J.E., 1997. Cyclopropane ring formation in membrane lipids of bacteria. Microbiol. Mol. Biol. Rev. 61, 429441.

Gupta, V.V.S.R., Roper, M.M., Kirkegaard, J.A., Angus, J.F., 1994. Changes in microbial biomass and organic matter levels during the first year of modified tillage and stubble management practices on a red earth. Aust. J. Soil Res. 32, 1339-1354.

Jenkinson, D.S., Ladd, J.N., 1981. Microbial biomass in soil: measurement and turnover. In: Paul, E.A., Ladd, J.N. (Eds.), Soil Biochemistry. Marcel Dekker, NY, pp. 415-471.

John, B., Ludwig, B., Potthoff, M., Flessa, H., 2004. Carbon and nitrogen mineralization after maize harvest between and within maize rows: a microcosm study using ${ }^{13} \mathrm{C}$ natural abundance. J. Plant Nutr. Soil Sci. 167, 270-276.

Johnson, C.K., Doran, J.W., Duke, H.R., Wienhold, B.J., Eskridge, K.M., Shanahan, J.F., 2001. Field-scale electrical conductivity mapping for delineating soil condition. Soil Sci. Soc. Am. J. 65 , 1829-1837.

Kaspar, T.C., Brown, H.J., Kassmeyer, E.M., 1991. Corn root distribution as affected by tillage, wheel traffic, and fertilized placement. Soil Sci. Soc. Am. J. 55, 1390-1394.

Kates, M., 1986. Techniques of lipidology: isolation, analysis and identification of lipids. In: Burdon, R.H., van Kippenberg, P.H. (Eds.), Laboratory Techniques in Biochemistry and Molecular Biology, Part 2, vol. 3. Elsevier, NY, pp. 464.

Kettler, T.A., Doran, J.W., Gilbert, T.L., 2001. A simplified method for soil particle size determination to accompany soil quality analyses. Soil Sci. Soc. Am. J. 65, 849-852.

Kroppenstedt, R.M., 1985. Fatty acid and menaquinon analysis of actinomycetes and related organisms. In: Goodfellow, M., Minnikin, D.E. (Eds.), Chemical Methods in Bacterial Systematics. Academic Press, London, pp. 173-199.

Olsson, P.A., Johansen, A., 2000. Lipid and fatty acid composition of hyphae and spores of arbuscular mycorrhizal fungi at different growth stages. Mycol. Res. 104, 429-434.

Pankhurst, C.E., Kirkby, C.A., Hawke, B.G., Harch, B.D., 2002. Impact of a change in tillage and crop residue management practice on soil chemical and microbiological properties in a cereal-producing red duplex soil in NSW. Aust. Biol. Fertil. Soils 35, 189-196.

Ritchie, S.W., Hanaway, J.J., Benson, G.O., 1997. How a Corn Plants Develops. Spec. Publ. 48. Iowa State Univ. Coop. Ext. Serv., Ames, IA

SAS Institute, 1999. SAS/STAT Software: Changes and Enhancements Through Release 8.0. SAS Inst., Cary, NC.

Smith, J.L., Doran, J.W., 1996. Measurement and use of pH and electrical conductivity for soil quality analysis. In: Doran, J.W., Jones, A.J. (Eds.), Methods for Assessing Soil Quality. ASA, CSSA, and SSSA, Madison, WI, pp. 169-186.

Stahl, P.D., Klug, M.J., 1996. Characterization and differentiation of filamentous fungi based on fatty acid composition. Appl. Environ. Microbiol. 62, 4136-4146.

Wander, M.M., Bollero, G.A., 1999. Soil quality assessment of tillage impacts in Illinois. Soil Sci. Soc. Am. J. 63, 961-971. 